\title{
Growth, chlorophyll fluorescence and gas exchange of pepper (Capsicum chinense Jacq.) plants in response to uptake and partitioning of nutrients
}

\author{
Rocío Meneses-Lazo ${ }^{1}$, René Garruña ${ }^{2 *}$, Ileana Echevarría-Machado ${ }^{3}$, Carlos Alvarado-López ${ }^{2}$, \\ Eduardo Villanueva-Couoh ${ }^{1}$, José Q. García-Maldonado ${ }^{4}$, and Jairo Cristóbal-Alejo ${ }^{1}$
}

\begin{abstract}
'Tecnológico Nacional de México, Instituto Tecnológico de Conkal, Av. Tecnológico s/n 97345, Conkal, Yucatán, México. ${ }^{2}$ Consejo Nacional de Ciencia y Tecnología, Instituto Tecnológico de Conkal, Av. Tecnológico s/n 97345, Conkal, Yucatán, México. *Corresponding author (renegh10@ hotmail.com).

${ }^{3}$ Centro de Investigación Científica de Yucatán, Unidad de Bioquímica y Biología Molecular de Plantas, Calle 43, número 130, Col. Chuburná de Hidalgo 97200, Mérida, Yucatán, México.

${ }^{4}$ Consejo Nacional de Ciencia y Tecnología, Centro de Investigación y de Estudios Avanzados, Unidad Mérida, Antigua carretera a Progreso km 6, Cordemex, Loma Bonita Xcumpich 97310, Mérida, Yucatán, México.
\end{abstract}

Received: 1 May 2020; Accepted: 27 July 2020; doi:10.4067/S0718-58392020000400585

\begin{abstract}
Habanero pepper (Capsicum chinense Jacq.) does not have a specific fertilization. Therefore, the aim of this study was to evaluate growth, photosynthesis and accumulation of macro and micronutrients of habanero pepper plants. Plants were established in nutrient film technique (NFT) hydroponic systems. Two universal balanced solutions (Steiner and Hoagland) were compared versus a conventional solution (control: Soria solution). The concentration of macro and micronutrients in roots, stems, and leaves, photosynthetic activity of plants, total nitrate, amino acid and protein contents, and growth parameters were evaluated. According to the results, concentrations of $\mathrm{K}, \mathrm{Mg}, \mathrm{Ca}, \mathrm{Cu}$ and $\mathrm{Zn}$ in plant tissues were higher in the Steiner and Hoagland treatments than control. In addition, the Steiner and Hoagland treatments increased the maximum photosynthetic rate $\left(\mathrm{A}_{\max }\right)\left(81 \%\right.$ and $80 \%$ respectively), light-saturated $\mathrm{CO}_{2}$ assimilation rate $\left(\mathrm{A}_{\text {sat }}\right)$ (3.8-fold and 3-fold, respectively) and maximum catalytic activities of Rubisco $\left(\mathrm{V}_{\text {cmax }}\right)(51 \%$ and $30 \%$ respectively) with respect to the control. Hoagland treatment increased total nitrate content $\left(3.66 \mathrm{mg} \mathrm{g}^{-1} \mathrm{FW}\right)$, but Steiner treatment increased amino acids in leaves (169.97 $\left.\mathrm{mg} \mathrm{g}^{-1} \mathrm{FW}\right)$ and control increased total proteins $\left(1.49 \mathrm{mg} \mathrm{g}^{-1} \mathrm{FW}\right)$. Steiner and Hoagland solutions significantly increased plant height (59\% and $41 \%$ respectively), leaf area (1.26-fold and 1.02-fold, respectively), and total dry mass $(80 \%$ and $69 \%$ respectively) with respect to the control solution. The results suggest that Steiner and Hoagland nutrient solutions provided nutrients that improve growth and photosynthetic activity. Moreover, total nitrate, amino acid and protein accumulation depend on the $\mathrm{N}$ source employed in nutrient solutions.
\end{abstract}

Key words: Growth, macronutrients, micronutrients, photosynthesis.

\section{INTRODUCTION}

In recent years, worldwide interest in the habanero pepper (Capsicum chinense Jacq.) crop has increased, due to the use of its fruits as one of the spiciest condiments in the world (Meneses-Lazo and Garruña, 2020). The Yucatan peninsula has the denomination of origin of habanero pepper and this is one of the areas with the highest yield in the world (MenesesLazo and Garruña, 2020). However, the fertilization used by producers is not based on balanced nutrient solutions that allow maximum nutrient utilization. Producers usually fertilize crops based on empirical knowledge (Alejo-Santiago et al., 2015). In habanero pepper, there are numerous nutrient solutions that were formulated empirically, without analyzing 
both concentrations and nutrient sources (Meneses-Lazo and Garruña, 2020). One of the formulations employed most is Soria et al. (2002) (125-100-150 kg ha- $\left.{ }^{-1} \mathrm{~N}-\mathrm{P}-\mathrm{K}\right)$. However, this solution does not include $\mathrm{Ca}, \mathrm{Mg}$, and S macronutrients, which are assumed to be found in adequate quantities in the soil. Also, this formulation uses urea as the main $\mathrm{N}$ source, which is highly polluting because its degradation products can be volatilized (between $40 \%$ and $50 \%$ ), in addition to requiring microorganisms so that $\mathrm{N}$ can be assimilated by plants (Staley et al., 2018).

On the other hand, one of the main problems in tropical vegetables is the heterogeneous growth of plants in the growth phase, the stage where producers suffer the greatest economic losses due to low quality plants that do not tolerate transplantation to the field (Garruña-Hernández et al., 2014). Poor nutrition is one of the issues to consider to solve this problem. Applying an appropriate amount of each nutrient allows plants to perform basic metabolic functions (NievesGonzález et al., 2015), which gives plants greater vigor during their growth and development. In this sense, the use of nutrient solutions with an ionic balance allows the efficient uptake of both water and nutrients by plants and their distribution to where they are required (Barker and Pilbeam, 2015). Therefore, it is necessary to use balanced nutrient solutions that supply the mineral demand that the plant requires. Nutrient film technique (NFT) hydroponic systems are ideal for conducting studies of nutrient uptake, distribution and accumulation in plants, because they allow the efficient evaluation of both nutrient source and plant demand (Asao, 2012).

Studies have been performed on the habanero pepper crop investigating the effect of some mineral elements on specific responses of plants (Pacheco-Arjona et al., 2011; Nieves-González et al., 2015). However, there are no studies on the effect of balanced nutrient solutions during the growth stage of habanero pepper plants. Therefore, the aim of this study was to evaluate both macro and micronutrient accumulation, growth and photosynthesis of habanero pepper plants cultivated in nutrient solutions.

\section{MATERIALS AND METHODS}

\section{Plant material and hydroponic systems}

The experiment was conducted at the Instituto Tecnológico de Conkal, Yucatan, Mexico. Habanero pepper (Capsicum chinense Jacq.) seeds were used (Geneseeds, Jalisco, Mexico). They were planted in 200-cavity polystyrene seedbeds using Canadian moss as substrate. Foliar fertilization (19:19:19 NPK, $1 \mathrm{~g} \mathrm{~L}^{-1}$, biweekly) started $20 \mathrm{~d}$ after sowing (das). At 50 das the plants were transplanted to nutrient film technique (NFT) hydroponic systems that were in a growth room $(4 \times 4 \times 2.2 \mathrm{~m})$ with controlled conditions: photosynthetic photon flux density (PPFD) was $450 \mu \mathrm{mol} \mathrm{m}^{-2} \mathrm{~s}^{-1}, 16: 8 \mathrm{~h}$ photoperiod, $22{ }^{\circ} \mathrm{C}$ and $60 \%$ RH. In each NFT system a data logger (HOBO U12-012, Onset Computer Corporation, Bourne, Massachusetts, USA) was used to measure environmental conditions. Each system had a $280 \mathrm{~L} \mathrm{~h}^{-1}$ submergible $^{\circ}$ pump (4.5 W, Aquakril, Queretaro, Mexico) to supply the corresponding nutrient solution with a film thickness of 1.5 $\mathrm{cm}$, gutters used were of polyvinyl chloride (PVC) with a diameter of $7.62 \mathrm{~cm}$, a $20 \mathrm{~L}$ bucket was connected to gutters to collect $12 \mathrm{~L}$ nutrient solution that were used in each system.

\section{Nutrient solutions}

Three nutrient solutions were used: Steiner (Steiner, 1984), Hoagland (Hoagland and Arnon, 1950), and Soria (Soria et al., 2002). Each solution was a treatment and each treatment was established in an independent NFT system. Steiner and Hoagland solutions were chosen as they are universal balanced solutions that include all essential macronutrients (N, P, K, $\mathrm{Ca}, \mathrm{Mg}$, and $\mathrm{S}$ ), whereas Soria solution was chosen as a control due to its use by habanero pepper producers in Yucatan. However, $\mathrm{N}$ and $\mathrm{P}$ sources were modified for this solution: ammonium nitrate was used instead of urea (to avoid the use of microorganisms that transform urea to ammonium) and monopotassium phosphate was used instead of phosphoric acid (to avoid low $\mathrm{pH}$ ). The three solutions were supplemented with micronutrients. For the Steiner and Hoagland solutions the recommended concentration for hydroponic crops was used, whereas for Soria solution the recommended concentration for fertigation crops was used. Calcium nitrate, potassium nitrate, ammonium nitrate, magnesium sulfate, potassium sulfate, monopotassium phosphate and micronutrients ( $\mathrm{Fe}, \mathrm{Mn}, \mathrm{Cu}, \mathrm{Zn}, \mathrm{B}$ and $\mathrm{Mo}$ ) were used as fertilizer sources (Table 1). Every third day the nutrient solution of the systems was changed, the $\mathrm{pH}$ was adjusted (from 5.5-6.0), and the dissolved oxygen $\left(>4 \mathrm{mg} \mathrm{L}^{-1}\right)$ and electrical conductivity $\left(\mathrm{EC} ; \leq 2 \mathrm{dS} \mathrm{cm}^{-1}\right)$ were measured in all treatments. 
Table 1. Formulation of nutrient solutions used in the growth stage of habanero pepper plants cultivated in nutrient film technique (NFT) hydroponic systems.

\begin{tabular}{|c|c|c|c|c|c|c|c|c|}
\hline \multirow[b]{2}{*}{ Treatments } & \multicolumn{7}{|c|}{ Macronutrients } & \multirow[b]{2}{*}{ Micronutrients } \\
\hline & $\mathrm{NO}_{3}^{-}$ & $\mathrm{H}_{2} \mathrm{PO}_{4}^{-}$ & $\mathrm{SO}_{4}{ }^{-2}$ & $\mathrm{~K}^{+}$ & $\mathrm{Ca}^{+2}$ & $\mathrm{Mg}^{+2}$ & $\overline{\mathrm{NH}_{4}{ }^{+}}$ & \\
\hline & 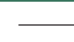 & & 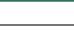 & meq $\mathrm{L}^{-1}$ & & & 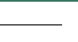 & $\mathrm{Mg} \mathrm{L}^{-1}$ \\
\hline Steiner & 12.0 & 1.0 & 7.0 & 7.0 & 9.0 & 4.0 & - & $20-30$ \\
\hline Hoagland & 14.0 & 1.0 & 4.0 & 6.0 & 8.0 & 4.0 & 1.0 & $20-30$ \\
\hline Soria (control) & 10.5 & 4.9 & - & 7.5 & - & - & 7.9 & $35-45$ \\
\hline
\end{tabular}

Micronutrients content (\% w/w): Fe-EDTA 7.5\%, Mn-EDTA 3.5\%, Cu-EDTA 0.28\%, Zn-EDTA 0.7\%, B 0.65\%, Mo $0.26 \%$

\section{Nutrient content of plants}

Thirty days after beginning the treatments, five plants per treatment were dried in a forced air oven at $70{ }^{\circ} \mathrm{C}$ for $72 \mathrm{~h}$. Then $\mathrm{P}, \mathrm{K}, \mathrm{Ca}, \mathrm{Mg}, \mathrm{Fe}, \mathrm{Mn}, \mathrm{Cu}$ and $\mathrm{Zn}$ contents were determined with the $\mathrm{X}$-ray microfluorescence technique (Bruker M4 Tornado 100; Berlin, Germany) at $50 \mathrm{kV}$ and $200 \mu \mathrm{A}$, without filters, under vacuum conditions at 20 mbar. Values in mass percentage were obtained and the element quantity in $\mathrm{mg} \mathrm{g}^{-1}$ dry mass was calculated based on the dry mass of the analyzed sample. On the other hand, total $\mathrm{N}$ determination (organic and inorganic) was performed with an $\mathrm{N}$ and $\mathrm{C}$ analyzer (Thermo Fisher, Waltham, Massachusetts, USA) using $10 \mathrm{mg}$ powdered sample per replicate.

For elementary analyses, five plants per treatment were used and they were analyzed per organ (roots, stems and leaves). With this data, total accumulation per plant was calculated.

\section{Chlorophyll contents and photosynthetic parameters}

To quantify chlorophylls a and $\mathrm{b}$ and total chlorophyll, $2 \mathrm{~g}$ fresh leaf tissue were used, which was macerated with liquid nitrogen. Then $3 \mathrm{~mL}$ acetone at $80 \%(\mathrm{v} / \mathrm{v})$ were added and shaken in a vortex for $30 \mathrm{~s}$. Samples were allowed to stand for $30 \mathrm{~min}$ at $4{ }^{\circ} \mathrm{C}$ in darkness and were centrifuged at $14000 \mathrm{rpm}$ for $30 \mathrm{~min}$. Supernatant volume was quantified and readings of acetone extracts at three wavelengths were performed $(645,652$ and $662 \mathrm{~nm})$. Then chlorophylls a and b and total chlorophyll contents were determined following the equations according to Val et al. (1985).

\section{Chlorophyll fluorescence}

Chlorophyll fluorescence parameters were measured in five plants per treatment with a pulse modulated amplitude fluorometer (PAM, Walz, Effeltrich, Germany). Measurements were taken at 60 das on the third leaf from the apex. Prior to measurement, the plants were acclimated in total darkness for $60 \mathrm{~min}$. Maximum quantum efficiency $\left(\mathrm{F}_{\mathrm{v}} / \mathrm{F}_{\mathrm{m}}\right)$, photochemical (qP) and non-photochemical (NPQ) quenching, electron transport rate (ETR) and quantum yield of photosystem II (PSII) $\left(\Phi_{\mathrm{PSII}}\right)$ were determined. The saturating light pulse and those used for $\mathrm{ETR}_{\mathrm{PSII}}$ and $\Phi_{\mathrm{PSII}}$ curves were recommended by Samaniego-Gámez et al. (2016).

\section{Gas exchange}

An infrared gas analyzer (LI6400xt,LI-COR,Lincoln, Nebraska, USA) was used to measure the response of photosynthesis $\left(\mathrm{CO}_{2}\right.$ assimilation rate; $\left.\mathrm{A}_{\mathrm{N}}\right)$ to the $\mathrm{CO}_{2}$ concentration inside leaf air spaces (intercellular $\mathrm{CO}_{2}$ concentration; $\mathrm{C}_{\mathrm{i}}$ ) and photosynthetic photon flux density (PPFD). Thus, photosynthetic $\mathrm{CO}_{2}$ response curves $\left(\mathrm{A}_{\mathrm{N}} / \mathrm{C}_{\mathrm{i}}\right)$ and photosynthetic light response curves $\left(\mathrm{A}_{\mathrm{N}} / \mathrm{PPFD}\right)$ were calculated. $\mathrm{CO}_{2}$ concentrations and PPFD used in the curves were recommended by Meneses-Lazo et al. (2018). The light-saturated $\mathrm{CO}_{2}$ assimilation rate $\left(\mathrm{A}_{\text {sat }}\right)$ and the maximum photosynthetic rate $\left(\mathrm{A}_{\max }\right)$ were calculated through von Caemmerer and Farquhar (1981) equations. The maximum catalytic activities of Rubisco $\left(\mathrm{V}_{\text {cmax }}\right)$, maximum rate of electron transport demand for RuBP regeneration $\left(\mathrm{J}_{\max }\right)$ and stomatal limitation were calculated according to Ethier and Livingston (2004). Five plants were evaluated per treatment.

\section{Total nitrate, amino acid and protein contents}

The protocol described by Santiago-Antonio et al. (2014) was followed for the extraction, starting from $1 \mathrm{~g}$ fresh leaf and root tissue. Total nitrate determination was performed according to Cawse (1967) using a $\mathrm{KNO}_{3}$ standard curve (Sigma Aldrich, St. Louis, Missouri, USA). Total amino acid analysis was performed according to Yemm and Cocking (1955) and total protein analysis was performed according to the method of Bradford (1976). 


\section{Dry mass and growth parameters}

To determine dry mass per organ and total dry mass, five plants per treatment were used in a forced air oven at $70{ }^{\circ} \mathrm{C}$ for $72 \mathrm{~h}, 30 \mathrm{~d}$ after beginning the experiment. To determine growth parameters, five plants per treatment were used. The number of leaves was recorded and leaf area was estimated with a leaf area meter (LI-3100, LICOR). Plant height and stem diameter were measured with a digital caliper (General Ultra-Tech, New York, USA).

\section{Experimental design and statistical analysis}

A completely randomized design with four replicates per treatment was used, each replicate with an independent NFT system. Three treatments (T1 $=$ Steiner's nutrient solution; T2 = Hoagland's nutrient solution; T3 = Control, Soria's nutrient solution) were evaluated. Experimental unit was 60 plants $(20 \mathrm{~cm}$ between plants). All parameters were evaluated in growth stage. The data were analyzed with ANOVA $(\mathrm{p} \leq 0.05)$ and Tukey's test $(\alpha=0.05)$. STATISTICA version 7 software (StatSoft, Tulsa, Oklahoma, USA) was used.

\section{RESULTS AND DISCUSSION}

\section{Macronutrients in habanero pepper plants}

In total macronutrient accumulation per plant, there were nonsignificant differences among treatments for $\mathrm{N}, \mathrm{P}$ and $\mathrm{S}$ (Figures 1A, 1B and 1C), whereas plants with the Steiner and Hoagland solutions increased total K (551 and $508 \mathrm{mg} \mathrm{g}^{-1}$ respectively), $\mathrm{Ca}$ (110 and $86 \mathrm{mg} \mathrm{g}^{-1}$ respectively), and $\mathrm{Mg}$ (7.44 and $5.37 \mathrm{mg} \mathrm{g}^{-1}$ respectively) contents compared to plants with the control solution (K: 386.49; Ca: 25.24; $\mathrm{Mg}$ : $0.61 \mathrm{mg} \mathrm{g}^{-1}$ ) (Figures 1D, 1E and 1F). In regard to macronutrient accumulation in leaves (Figures 1A, 1B, 1C, 1D, 1E and 1F), the trend was similar to total accumulation per plant. It is likely that because this was the organ with the greatest nutrient accumulation, it influenced total accumulation per plant more than other organs such as roots and stems. In the stems, significant differences were only observed in N (Steiner: 39.63, Hoagland: 49.31 and Control: $48.72 \mathrm{mg} \mathrm{g}^{-1}$ ), K (Steiner: 92.63, Hoagland: 86.8 and Control: $60.5 \mathrm{mg} \mathrm{g}^{-1}$ ) and Ca (Steiner: 20.73, Hoagland: 15.67 and Control: $6.9 \mathrm{mg} \mathrm{g}^{-1}$ ) (Figures 1A, 1D and 1E). The plant roots in Steiner and Hoagland solutions significantly exceeded those of the control solution in the accumulation of $\mathrm{P}\left(3.8,3.39\right.$ and $2.38 \mathrm{mg} \mathrm{g}^{-1}$ respectively), $\mathrm{S}$ (3.41, 2.35 and $1.64 \mathrm{mg} \mathrm{g}^{-1}$ respectively), $\mathrm{K}$ (89.81, 94.03 and $37.47 \mathrm{mg} \mathrm{g}^{-1}$ respectively), Ca (14.71, 13.9 and $5.5 \mathrm{mg} \mathrm{g}^{-1}$ respectively) and $\mathrm{Mg}\left(0.46,0.36\right.$ and $0.06 \mathrm{mg} \mathrm{g}^{-1}$ respectively) (Figures $1 \mathrm{~B}, 1 \mathrm{C}, 1 \mathrm{D}, 1 \mathrm{E}$ and $\left.1 \mathrm{~F}\right)$. However, $\mathrm{N}$ accumulation in roots was greater with control solution than Hoagland solution (60.1 and $52.93 \mathrm{mg} \mathrm{g}^{-1}$ respectively) (Figure 1A).

During the growth stage, it is possible to use $\mathrm{N}$ sources based on $\mathrm{NO}_{3}^{-}$and switch to $\mathrm{NH}_{4}{ }^{+}$and $\mathrm{NO}_{3}^{-}(20 \% / 80 \%$, respectively) in yield stages (Tucuch-Haas et al., 2012). Zhang et al. (2019) mention that plants prefer $\mathrm{N}$ in the form of $\mathrm{NH}_{4}{ }^{+}$because its assimilation to amino acids within the plant is immediate, whereas $\mathrm{NO}_{3}^{-}$requires more energy for its transformation to $\mathrm{NH}_{4}{ }^{+}$. In this sense, Steiner solution only uses $\mathrm{NO}_{3}{ }^{-}$as an available $\mathrm{N}$ source, whereas $\mathrm{NO}_{3}{ }^{-}$and $\mathrm{NH}_{4}{ }^{+}$ were used in the Hoagland and control solutions, so the $\mathrm{N}$ source in these solutions was high. However, when there is a higher $\mathrm{NH}_{4}{ }^{+}$concentration, uptake of other nutrients such as $\mathrm{K}, \mathrm{Ca}$, Mg becomes less efficient (Barker and Pilbeam, 2015), this was observed with $\mathrm{K}^{+}$, its accumulation in control plants was lower, probably due to competition with $\mathrm{NH}_{4}{ }^{+}$for highaffinity transport systems (Pacheco-Arjona et al., 2011). Similarly, the control solution does not include S, Ca and Mg in its formulation, although low concentrations of these macronutrients were found. According to Gayosso-Rodríguez et al. (2018), moss of the genus Sphagnum may contain $\mathrm{Na}, \mathrm{Ca}, \mathrm{Mg}, \mathrm{K}$ and phosphates in its nutrient composition. In this sense, during the seedbed stage (before transplanting) Canadian moss was used for both germination and growth of habanero pepper seedlings, and therefore $\mathrm{Ca}$ and $\mathrm{Mg}$ concentrations were probably obtained in this period of time. On the other hand, $\mathrm{Na}$ et al. (2014) mention that $\mathrm{NO}_{3}{ }^{-}$can increase $\mathrm{Ca}^{+2}$ uptake, whereas $\mathrm{NH}_{4}{ }^{+}$can limit it. This possibly increased $\mathrm{Ca}^{+2}$ accumulation in plants with the Steiner and Hoagland solutions. In the case of S, its presence in plants with the control solution is possibly due to small concentrations of potassium sulfate (1.8\%) in the commercial fertilizer used (potassium nitrate, Ultrasol NKS, Mexico). The difference among $\mathrm{SO}_{4}^{-2}$ concentrations in roots is possibly due to the presence of $\mathrm{NH}_{4}{ }^{+}$, which can limit its uptake (Barker and Pilbeam, 2015). 
Figure 1. Total N (A), P(B), S (C), K (D), Ca (E) and Mg (F) contents in habanero pepper plants with three nutrient solutions.

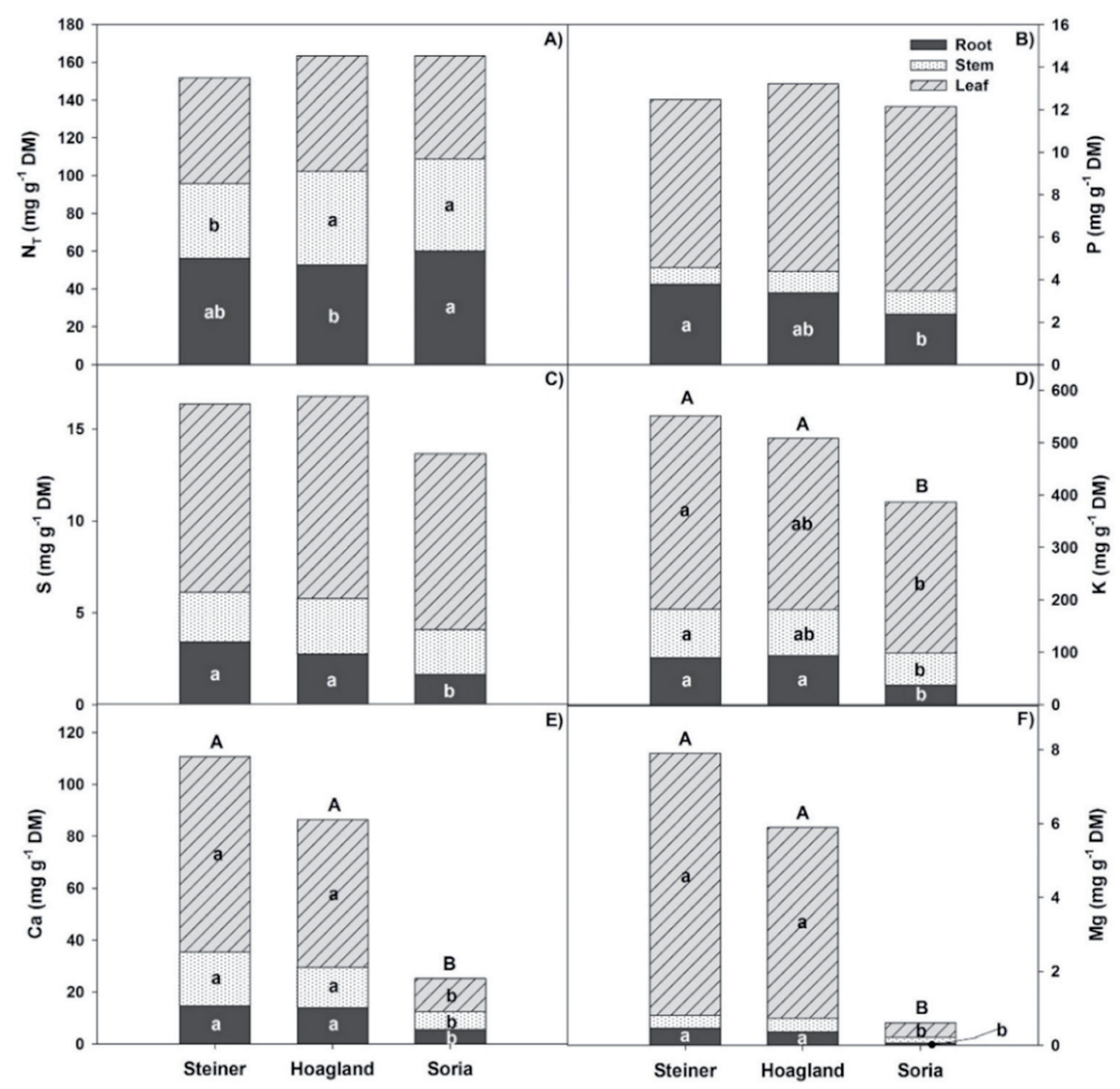

Data are means \pm SE; different letters (lowercase letter: in root, stem and leaf; uppercase letter: in complete plant) show significant differences among treatments according to Tukey's test $(\alpha=0.05) ; \mathrm{n}=5$.

\section{Micronutrients in habanero pepper plants}

In accumulated micronutrient concentrations per plant, for both total Fe and $\mathrm{Mn}$ per plant there were nonsignificant differences among treatments (Figures 2A and 2B). However, the Steiner and Hoagland solutions increased $\mathrm{Cu}(0.17$ and $0.13 \mathrm{mg} \mathrm{g}^{-1}$ respectively) and $\mathrm{Zn}\left(0.44\right.$ and $0.51 \mathrm{mg} \mathrm{g}^{-1}$ respectively) accumulation compared to the control solution $\left(\mathrm{Cu}: 0.065 ; \mathrm{Zn}: 0.22 \mathrm{mg} \mathrm{g}^{-1}\right.$ ) (Figures $2 \mathrm{C}$ and 2D). In regard to $\mathrm{Fe}$ and $\mathrm{Zn}$ concentration in leaves, there were nonsignificant differences among treatments, whereas $\mathrm{Cu}$ was not detected in leaves by $\mathrm{X}$-ray microfluorescence equipment (Figures $2 \mathrm{~A}, 2 \mathrm{C}$ and 2D), possibly due to low or zero $\mathrm{Cu}$ concentrations in the leaves. In the roots, Steiner and Hoagland solutions increased $\mathrm{Mn}$ (3.32 and $2.61 \mathrm{mg} \mathrm{g}^{-1}$ respectively), $\mathrm{Cu}\left(0.156\right.$ and $0.1 \mathrm{mg} \mathrm{g}^{-1}$ respectively) and $\mathrm{Zn}\left(0.56\right.$ and $0.52 \mathrm{mg} \mathrm{g}^{-1}$ respectively) accumulation compared to the control solution ( $\mathrm{Mn}: 1.41 ; \mathrm{Cu}: 0.05 ; \mathrm{Zn}: 0.11 \mathrm{mg} \mathrm{g}^{-1}$ ) (Figures 2B, 2C and 2D). In the stems, Mn was higher with the control solution $\left(0.83 \mathrm{mg} \mathrm{g}^{-1}\right)$ (Figure 2B), whereas $\mathrm{Zn}$ accumulated more with the Hoagland solution $\left(0.11 \mathrm{mg} \mathrm{g}^{-1}\right.$ ) (Figure 2D). In the leaves, Mn was higher with the control solution (1.58 $\left.\mathrm{mg} \mathrm{g}^{-1}\right)$ compared to Steiner and Hoagland solutions ( 0.58 and $0.73 \mathrm{mg} \mathrm{g}^{-1}$ respectively). In the case of Mo, concentrations could not be quantified in any plant organ.

In contrast to macronutrients, all micronutrients accumulated more in the roots than the aerial part, due to their low mobility within the plant (Marschner, 2012). In case of Mn, its uptake in plants increases when the nutrient solution is acidified by the presence of $\mathrm{H}^{+}$protons (Aftab and Hakeem, 2020). In this sense, the $\mathrm{pH}$ of the control solution was acidified with $\mathrm{NH}_{4}{ }^{+}(\mathrm{pH}$ between 4.9 and 5.5), and this probably favored a higher Mn uptake and its distribution in the 
Figure 2. Iron (A), Mn (B), Cu (C) and $\mathrm{Zn}$ (D) contents in habanero pepper plants with three nutrient solutions.

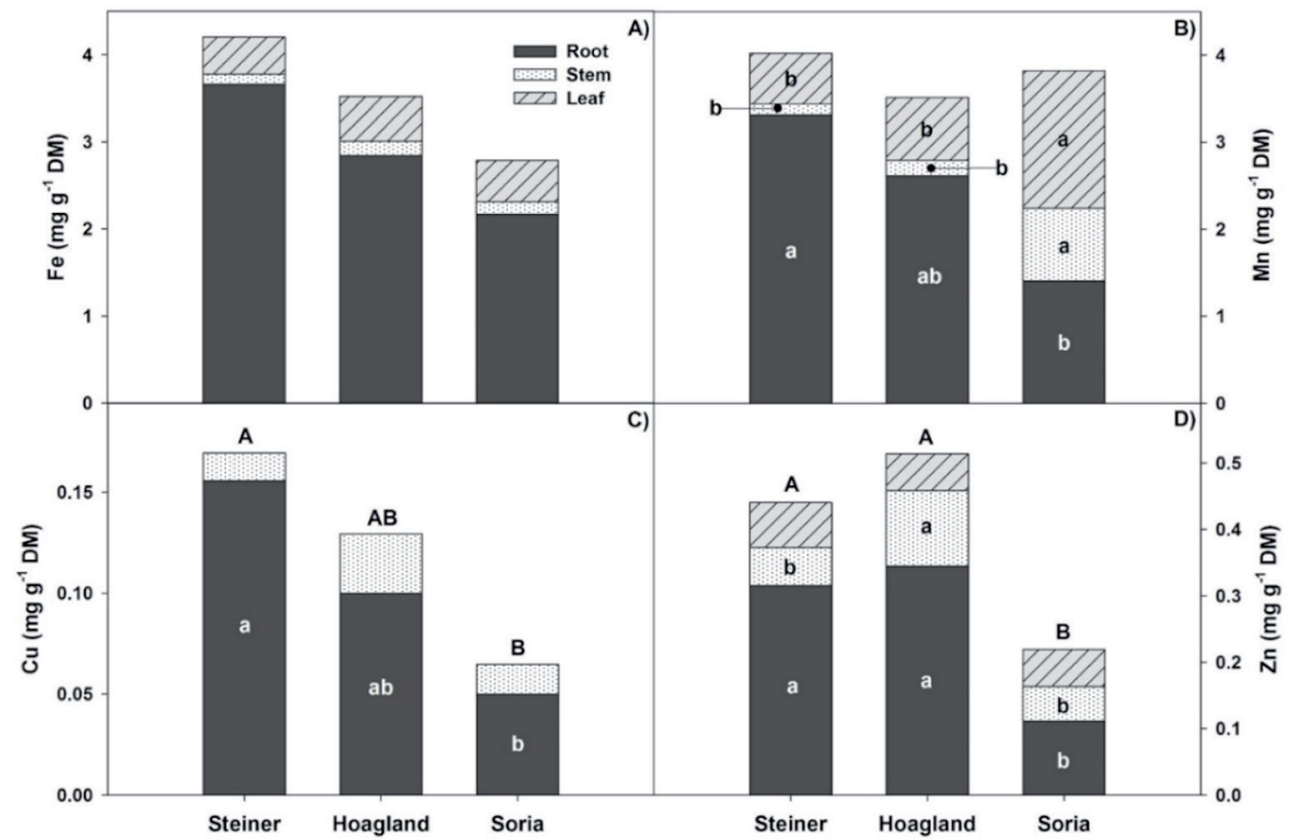

Data are means \pm SE; different letters (lowercase letter: in root, stem and leaf; uppercase letter: in complete plant) show significant differences among treatments according to Tukey's test $(\alpha=0.05) ; \mathrm{n}=5$.

plant (Figure 2B). On the other hand, $\mathrm{Cu}$ was the only micronutrient which concentrations in habanero pepper leaves were not recorded. In this regard, Marschner (2012) showed that $\mathrm{Cu}$ is accumulated in the roots and has low translocation to the aerial part. This element can modify both root growth and morphology. In the case of $\mathrm{Zn}$, its uptake can be limited when $\mathrm{NH}_{4}{ }^{+}$is used as the main $\mathrm{N}$ source (Barker and Pilbeam, 2015), which could explain its low concentrations in habanero pepper plants with the control solution.

\section{Chlorophyll contents}

In habanero pepper plants with Steiner solution there were higher Chl $a\left(76.93 \mu \mathrm{g} \mathrm{mL}^{-1}\right), \mathrm{Chl} b\left(38.87 \mu \mathrm{g} \mathrm{mL}^{-1}\right)$ and total $\mathrm{Chl}_{\mathrm{atb}}\left(115.8 \mu \mathrm{g} \mathrm{mL}^{-1}\right)$ contents compared to plants with the Hoagland (Chl $a: 52.71 \mu \mathrm{g} \mathrm{mL}^{-1}$; Chl $b: 27.58 \mu \mathrm{g} \mathrm{mL}^{-1}$; total $\left.\mathrm{Chl}_{a+b}: 80.29 \mu \mathrm{g} \mathrm{mL}^{-1}\right)$ and control (Chl $a: 45.28 \mu \mathrm{g} \mathrm{mL}^{-1}$; Chl $b: 18.85 \mu \mathrm{g} \mathrm{mL}^{-1}$; total $\mathrm{Chl}_{a+b}: 64.13 \mu \mathrm{g} \mathrm{mL}^{-1}$ ) solutions (Figures 3A, 3B, and 3C). On the other hand, the $\mathrm{Chl} a / \mathrm{Chl} b$ ratio in plants with the control solution (2.4) showed higher values than the other treatments (Steiner: 1.98, Hoagland: 1.91) (Figure 3D).

Chlorophyll's structure has a porphyrin ring containing $\mathrm{Mg}$, so the presence of this element is essential for synthesis of chlorophylls (Marschner, 2012). In this context, is possible that Mg supply in the Steiner and Hoagland solutions increased chlorophyll concentration. Nevertheless, the $\mathrm{Chl} a / \mathrm{Chl} b$ ratio was higher in plants with the control solution. Albanese et al. (2016) remark that the increase in values of the $\mathrm{Chl} a / \mathrm{Chl} b$ ratio is due to an increase in reaction centers when plants grow under high light intensities. However, light intensity was the same in the three treatments, but it is possible that plants with the control solution invested the little $\mathrm{Mg}$ they had to generate more $\mathrm{Chl} a$ than $\mathrm{Chl} b$ and guarantee electron transport in the photosystems. On the other hand, Chen et al. (2010) mention that both Chl $a$ and $\mathrm{Chl} b$ are involved in the harvesting of light energy, but only $\mathrm{Chl} a$ is indispensable in energy transduction at reaction centers of the photosystems.

\section{Chlorophyll fluorescence}

Maximum quantum efficiency $\left(\mathrm{F}_{\mathrm{v}} / \mathrm{F}_{\mathrm{m}}\right)$, photochemical (qP) and non-photochemical (NPQ) quenching (Table 2) and maximum quantum yield of PSII ( $\left.\Phi_{\text {PSII }}\right)$ (Figure $4 \mathrm{~B}$ ) did not show significant differences among treatments. However, plants with the Steiner and Hoagland solutions had a greater electron transport rate (ETR) than plants with the control solution from $1200 \mu \mathrm{mol}$ photons $\mathrm{m}^{-2} \mathrm{~s}^{-1}$ upwards (Figure 4A). 
Figure 3. Chlorophyll a $(\mathrm{Chl} a)(\mathrm{A})$, chlorophyll b $(\mathrm{Chl} b)(\mathrm{B})$, total chlorophylls $\left(\mathrm{Chl}_{\mathrm{a}+\mathrm{b}}\right)(\mathrm{C})$, and $\mathrm{Chl} a / \mathrm{Chl} b$ ratio (D) in habanero pepper plants with three nutrient solutions.

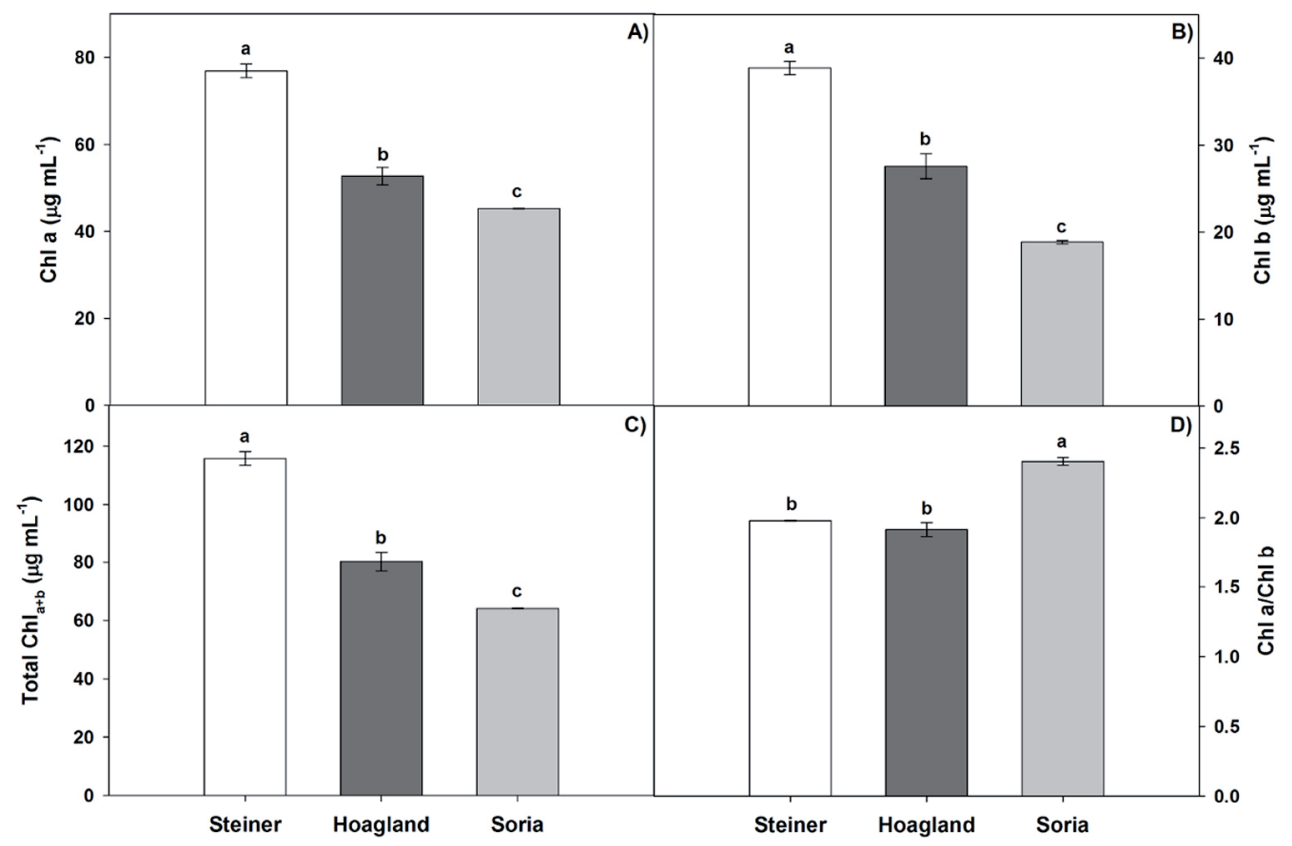

Data are means \pm SE; different letters show significant differences among treatments according to Tukey's test $(\alpha=0.05) ; \mathrm{n}=5$.

Table 2. Maximum quantum efficiency $\left(F_{v} / F_{m}\right)$, photochemical $(q P)$ and non-photochemical (NPQ) quenching in habanero pepper plants with three nutrient solutions.

\begin{tabular}{lccc}
\hline Treatments & $\mathrm{F}_{\mathrm{v}} / \mathrm{F}_{\mathrm{m}}$ & $\mathrm{qP}$ & $\mathrm{NPQ}$ \\
\hline Steiner & $0.79 \pm 0.03$ & $0.25 \pm 0.02$ & $0.14 \pm 0.02$ \\
Hoagland & $0.80 \pm 0.05$ & $0.26 \pm 0.04$ & $0.23 \pm 0.08$ \\
Soria (control) & $0.77 \pm 0.01$ & $0.24 \pm 0.02$ & $0.24 \pm 0.02$ \\
\hline \multicolumn{2}{l}{ Data are means $\pm \mathrm{SE} ; \mathrm{n}=15}$. & &
\end{tabular}

Figure 4. Electron transport rate (ETR) (A) and maximum quantum yield of photosystem II ( $\left.\Phi_{\mathrm{PSII}}\right)(\mathrm{B})$.
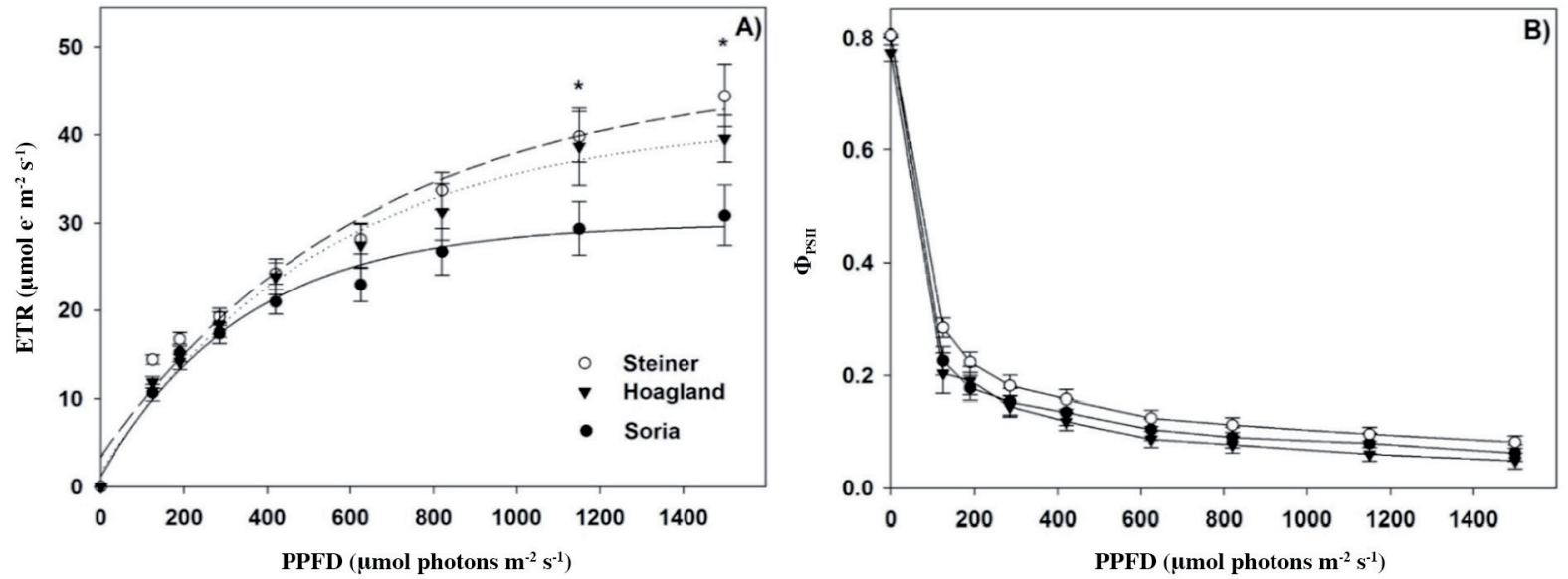

Data are means $\pm \mathrm{SE}$; *Significant differences (ANOVA, $\mathrm{p} \leq 0.05$ ); $\mathrm{n}=15$; PPFD: photosynthetic photon flux density. 
Despite not finding differences in chlorophyll fluorescence, a higher electron transport rate (ETR) was recorded in habanero pepper plants with the Steiner and Hoagland solutions. According to Fu et al. (2014), extreme light and temperature conditions can cause the closure of reaction centers affecting leaf photochemistry. However, light and temperature conditions were appropriate for plants in all treatments, so it is likely that no differences were observed. On the other hand, it is very likely that the differences observed in the ETR were due to increased Chl $a$ concentration, as discussed previously.

\section{Gas exchange}

In the $A_{N} / C_{i}$ response curves, plants with the Steiner and Hoagland solutions reached their compensation point with lower intercellular $\mathrm{CO}_{2}$ concentration (109 and $105 \mu \mathrm{mol} \mathrm{CO} \mathrm{mol}^{-1}$ respectively) and had higher saturation points (Steiner: $22.1 \mu \mathrm{mol} \mathrm{CO} \mathrm{Cm}^{-2} \mathrm{~s}^{-1}$ and Hoagland: $\left.22 \mu \mathrm{mol} \mathrm{CO} \mathrm{CO}^{-2} \mathrm{~s}^{-1}\right)$ than plants with the control solution $\left(177 \mu \mathrm{mol} \mathrm{CO}_{2} \mathrm{~mol}^{-1}\right.$ and $12.2 \mu \mathrm{mol} \mathrm{CO}_{2} \mathrm{~m}^{-2} \mathrm{~s}^{-1}$ respectively) (Figure 5A). In the $\mathrm{A}_{\mathrm{N}} / \mathrm{PPFD}$ response curves, plants with the Steiner and Hoagland solutions reached their compensation points with a lower amount of light photons (52 and $61 \mu \mathrm{mol}$ photons $\mathrm{m}^{-2} \mathrm{~s}^{-1}$ respectively) and reached higher saturation points (Steiner: 13.4 and Hoagland: $11.2 \mu \mathrm{mol} \mathrm{CO}_{2} \mathrm{~m}^{-2} \mathrm{~s}^{-1}$ ) than plants with the control solution (209 $\mu \mathrm{mol}$ photons $\mathrm{m}^{-2} \mathrm{~s}^{-1}$ and $2.8 \mu \mathrm{mol} \mathrm{CO} \mathrm{CO}^{-2} \mathrm{~s}^{-1}$ respectively) (Figure $5 \mathrm{~B}$ ).

Considering that $\mathrm{P}$ is directly involved in the Calvin-Benson-Bassham cycle and $\mathrm{P}$ concentrations were similar among treatments, this element is ruled out as the cause of the increase in photosynthesis in plants with the Steiner and Hoagland solutions. However, increased $\mathrm{C}$ assimilation is a consequence of the rise in electron transport rate (ETR) from PSII to PSI (Figure 4A). This increases the availability of ATP and NADPH in the Calvin-Benson-Bassham cycle and, at the same time, carboxylation of intercellular $\mathrm{CO}_{2}$ (Sekhar et al., 2014).

In the Steiner and Hoagland treatments, maximum photosynthetic rate $\left(\mathrm{A}_{\max }\right)\left(22.1\right.$ and $22 \mu \mathrm{mol} \mathrm{CO} \mathrm{m}^{-2} \mathrm{~s}^{-1}$ respectively), light-saturated $\mathrm{CO}_{2}$ assimilation rate $\left(\mathrm{A}_{\text {sat }}\right)\left(13.4\right.$ and $11.2 \mu \mathrm{mol} \mathrm{CO}_{2} \mathrm{~m}^{-2} \mathrm{~s}^{-1}$ respectively), maximum catalytic activities of Rubisco $\left(\mathrm{V}_{\text {cmax }}\right)$ (65 and $56 \mu \mathrm{mol} \mathrm{CO} \mathrm{CO}_{2} \mathrm{~m}^{-2} \mathrm{~s}^{-1}$ respectively), and maximum rate of electron transport demand for RuBP regeneration ( $\left.\mathrm{J}_{\max }\right)\left(125\right.$ and $122 \mu \mathrm{mol} \mathrm{e} \mathrm{e}^{-2} \mathrm{~s}^{-1}$ respectively) were significantly higher than plants with the control solution ( $\mathrm{A}_{\text {sat }}: 2.8 \mu \mathrm{mol} \mathrm{CO} \mathrm{m}^{-2} \mathrm{~s}^{-1}, \mathrm{~A}_{\max }: 12.2 \mu \mathrm{mol} \mathrm{CO} \mathrm{m}^{-2} \mathrm{~s}^{-1}, \mathrm{~V}_{\text {cmax }}: 43 \mu \mathrm{mol} \mathrm{CO} \mathrm{m}^{-2} \mathrm{~s}^{-1}$ and $\mathrm{J}_{\text {max }}: 110 \mu \mathrm{mol} \mathrm{e} \mathrm{m}^{-2} \mathrm{~s}^{-1}$ ) (Table 3). Also, plants with the control solution had greater stomatal limitation (50\%) than those with the Steiner and Hoagland solutions (14\% and $6 \%$ respectively).

Figure 5. Photosynthetic $\mathrm{CO}_{2}$ response curves $\left(A_{N} / C_{i}\right)(A)$ and photosynthetic light response curves $\left(A_{N} / P P F D\right)(B)$ in habanero pepper plants with three nutrient solutions.

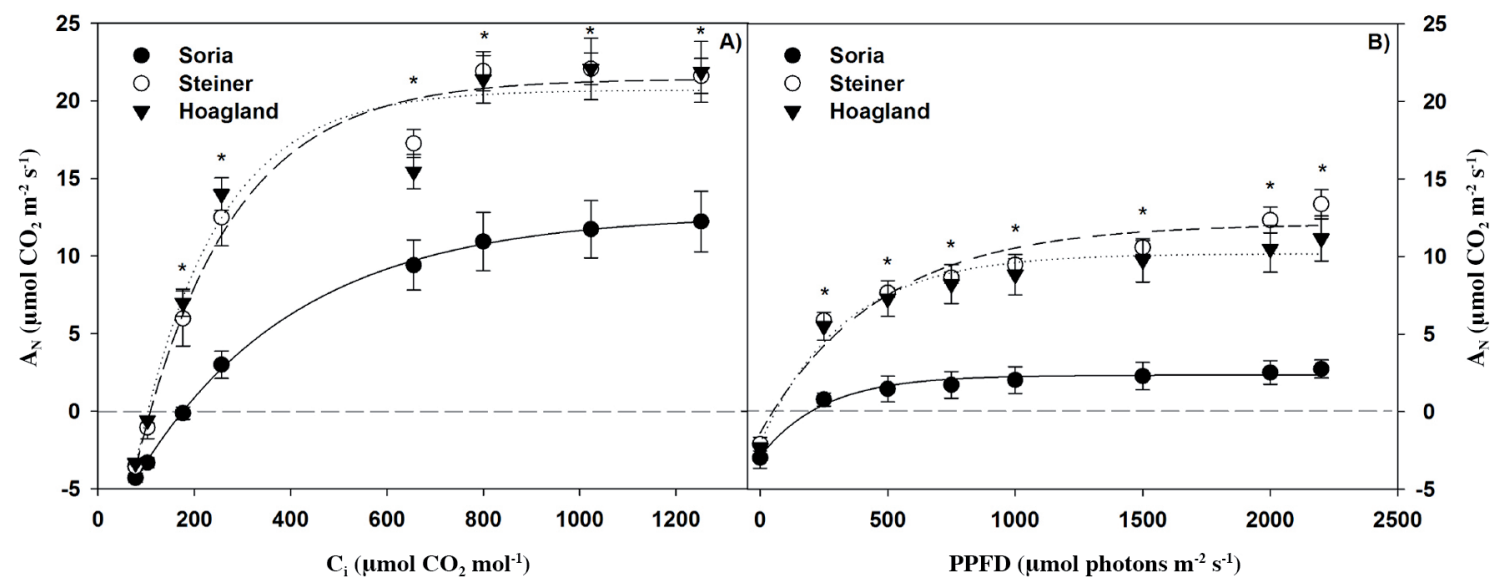

Data are means \pm SE plotted with a defined fitting equation $\left(\mathrm{R}^{2}=0.97\right.$ and 0.98 respectively); $*$ Significant differences (ANOVA, $\left.\mathrm{p} \leq 0.05\right) ; \mathrm{n}=15$ $\mathrm{A}_{\mathrm{N}}: \mathrm{CO}_{2}$ assimilation rate; $\mathrm{C}_{\mathrm{i}}$ : intercellular $\mathrm{CO}_{2}$ concentration; PPFD: photosynthetic photon flux density. 
Table 3. Maximum photosynthetic rate $\left(\mathrm{A}_{\max }\right)$, light-saturated $\mathrm{CO}_{2}$ assimilation rate $\left(\mathrm{A}_{\text {sat }}\right)$, maximum catalytic activities of Rubisco $\left(V_{\text {cmax }}\right)$, maximum rate of electron transport demand to $R u B P$ regeneration $\left(J_{\max }\right)$ and stomatal limitation (I) in habanero pepper plants with three nutrient solutions.

\begin{tabular}{|c|c|c|c|c|c|}
\hline Treatments & $\mathrm{A}_{\max }$ & $\mathrm{A}_{\text {sat }}$ & $\mathrm{V}_{\text {cmax }}$ & $J_{\max }$ & 1 \\
\hline & 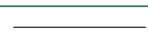 & $\mathrm{nol} \mathrm{CO} 2 \mathrm{~m}^{-2} \mathrm{~s}^{-1}$ & - & $\mu \mathrm{mol} \mathrm{e}-\mathrm{m}^{-2} \mathrm{~s}^{-1}$ & $\%$ \\
\hline Steiner & $22.1 \pm 1.0 \mathrm{a}$ & $13.4 \pm 0.9 \mathrm{a}$ & $65 \pm 4.2 \mathrm{a}$ & $125 \pm 4.7 \mathrm{a}$ & $14 \pm 1.3 b$ \\
\hline Hoagland & $22.0 \pm 1.9 \mathrm{a}$ & $11.2 \pm 1.4 \mathrm{a}$ & $56 \pm 4.4 \mathrm{a}$ & $122 \pm 5.1 \mathrm{a}$ & $6 \pm 0.8 \mathrm{c}$ \\
\hline Soria (control) & $12.2 \pm 1.9 b$ & $2.8 \pm 0.5 b$ & $43 \pm 3.1 b$ & $110 \pm 5.5 b$ & $50 \pm 4.8 \mathrm{a}$ \\
\hline
\end{tabular}

Data are means \pm SE; different letters in columns show significant differences according to Tukey's test $(\alpha=0.05) ; \mathrm{n}=15$.

It is evident that the stomatal limitation presented by plants with the control solution affected all photosynthetic parameters. Some authors (Marschner, 2012; Barker and Pilbeam, 2015) suggest that $\mathrm{K}^{+}$is closely involved in opening and closing stomata, and a decrease in $\mathrm{K}^{+}$concentration can affect proper stomatal function. In this study, the plants with Steiner solution had the highest $\mathrm{K}$ concentration in both the whole plant $\left(551.23 \mathrm{mg} \mathrm{g}^{-1}\right)$ and leaves $\left(368.8 \mathrm{mg} \mathrm{g}^{-1}\right)$ (Figure 1D) and were the ones that presented the lowest stomatal limitation, in contrast to plants with the control solution. In this sense, $\mathrm{NH}_{4}{ }^{+}$concentrations in the control solution possibly limited $\mathrm{K}^{+}$uptake in habanero pepper plants, due to great competitiveness for high-affinity transporters required for K (Pacheco-Arjona et al., 2011; Barker and Pilbeam, 2015).

\section{Total nitrate, amino acid and protein contents}

Plants with the Hoagland solution recorded greater total nitrate accumulation in fresh leaf $\left(2.07 \mathrm{mg} \mathrm{g}^{-1} \mathrm{FW}\right)$ and root (1.6 $\mathrm{mg} \mathrm{g}^{-1} \mathrm{FW}$ ) tissues compared to those with the Steiner solution (1.8 and $1.5 \mathrm{mg} \mathrm{g}^{-1} \mathrm{FW}$ respectively) (Figures 6A and 6B). Plant leaves with the Steiner solution recorded greater total amino acid accumulation $\left(170 \mathrm{mg} \mathrm{g}^{-1} \mathrm{FW}\right)$ (Figure 6C), whereas in the roots no differences were found among treatments (Figure 6D). In total protein content, it was observed that plants with the control solution had higher values in leaves $\left(0.921 \mathrm{mg} \mathrm{g}^{-1} \mathrm{FW}\right)$ and roots $\left(0.57 \mathrm{mg} \mathrm{g}^{-1} \mathrm{FW}\right)$ compared to plants with the Steiner (leaves: 0.79, roots: $0.49 \mathrm{mg} \mathrm{g}^{-1} \mathrm{FW}$ ) and Hoagland (leaves: 0.57, roots: $0.44 \mathrm{mg} \mathrm{g}^{-1}$ FW) solutions (Figures 6E and 6F).

The use of $\mathrm{N}$ in habanero pepper plants probably depends on available $\mathrm{N}$ sources and the concentration in which they are applied. Nitrogen accumulation in the form of total nitrates is related to an increase in dry biomass, because it increases root growth and regulates foliar expansion by implementing $\mathrm{NO}_{3}{ }^{-}$as the main $\mathrm{N}$ source (Santiago-Antonio et al., 2014). In this sense, the control solution contributed $\mathrm{N}$ in the form of $\mathrm{NO}_{3}{ }^{-}$and $\mathrm{NH}_{4}{ }^{+}$in concentrations of 10.5 and 7.9 meq L ${ }^{-1}$, and this probably generated a preferential uptake of $\mathrm{NH}_{4}{ }^{+}$over $\mathrm{NO}_{3}{ }^{-}$because it does not represent a higher energy cost for plants (Zhang et al., 2019). On the other hand, amino acids accumulate in greater quantity in the aerial part (Santiago-Antonio et al., 2014). In this sense, both $\mathrm{NH}_{4}{ }^{+}$and $\mathrm{NO}_{3}{ }^{-}$can be incorporated into organic forms through the glutamine synthetase/glutamate synthase (GS/GOGAT) cycle to produce amino acids or proteins. Considering this occurs when $\mathrm{NH}_{4}{ }^{+}$concentrations are high (Barker and Pilbeam, 2015), it could be the case with the control solution.

\section{Growth parameters in habanero pepper plants}

Nonsignificant differences were observed between Steiner and Hoagland treatments. However, both plant height and leaf area in plants with the Steiner $\left(17.28 \mathrm{~cm}\right.$ and $351.26 \mathrm{~cm}^{2}$ respectively) and Hoagland $(15.32 \mathrm{~cm}$ and 314.53 $\mathrm{cm}^{2}$ respectively) solutions were greater than plants with the control solution $\left(10.9 \mathrm{~cm}\right.$ and $155.66 \mathrm{~cm}^{2}$ respectively). Plants with the Hoagland solution (70 leaves) had a greater number of leaves than those with the control solution (39 leaves) and there were no differences in stem diameter among treatments (Figure 7). The same trend was observed in dry mass accumulation as in the growth parameters, with no differences between the Steiner and Hoagland treatments. However, plants with the Steiner and Hoagland solutions increased dry mass accumulation in the leaves (1.12 and $1.13 \mathrm{~g}$ respectively), roots ( 0.52 and $0.49 \mathrm{~g}$ respectively) and in total (2.16 and $2.04 \mathrm{~g}$ respectively) compared to those with the control solution (0.69, 0.22 and $1.02 \mathrm{~g}$ respectively) (Figure 8).

In this study, the Steiner and Hoagland solutions increased dry biomass, plant height and leaf area. These treatments had higher $\mathrm{Ca}$ and $\mathrm{Mg}$ concentrations that promoted both cellular division and chlorophyll synthesis respectively (Barker and Pilbeam, 2015), which helped to increase both leaf area and photosynthetic rate. Therefore, the growth of habanero pepper plants in Steiner and Hoagland solutions is a consequence of the accumulation of macro and micronutrients, and their physiological and biochemical activities. 
Figure 6. Total nitrates in leaves (A) and roots (B), total amino acids in leaves (C) and roots (D), and total proteins in leaves $(\mathrm{E})$ and roots $(\mathrm{B})$ in habanero pepper plants with three nutrient solutions.

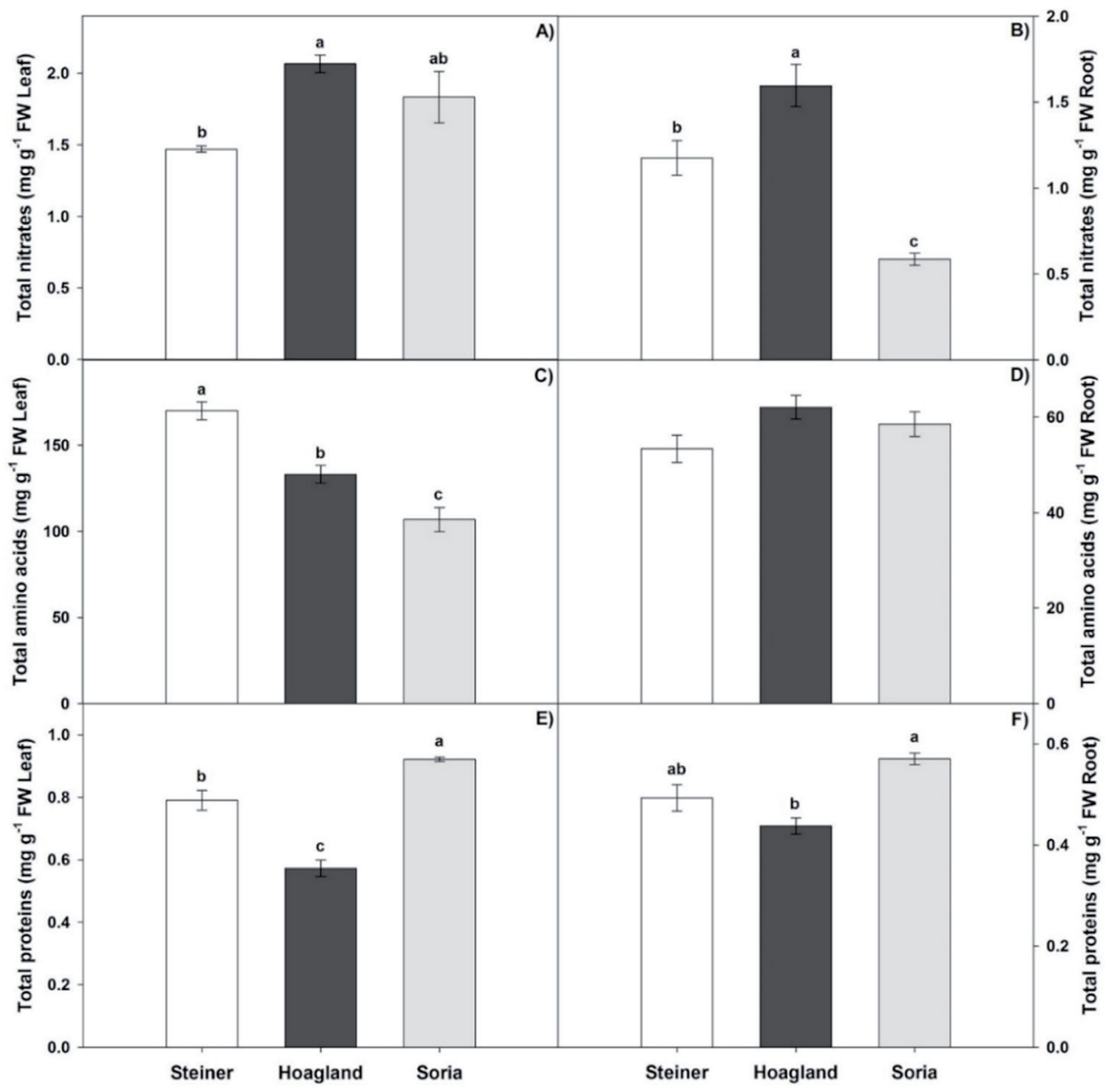

Data are means \pm SE; different letters show significant differences according to Tukey's test $(\alpha=0.05) ; n=5$. 
Figure 7. Plant height (A), stem diameter (B), number of leaves (C) and leaf area (D) of habanero pepper plants with three nutrient solutions.

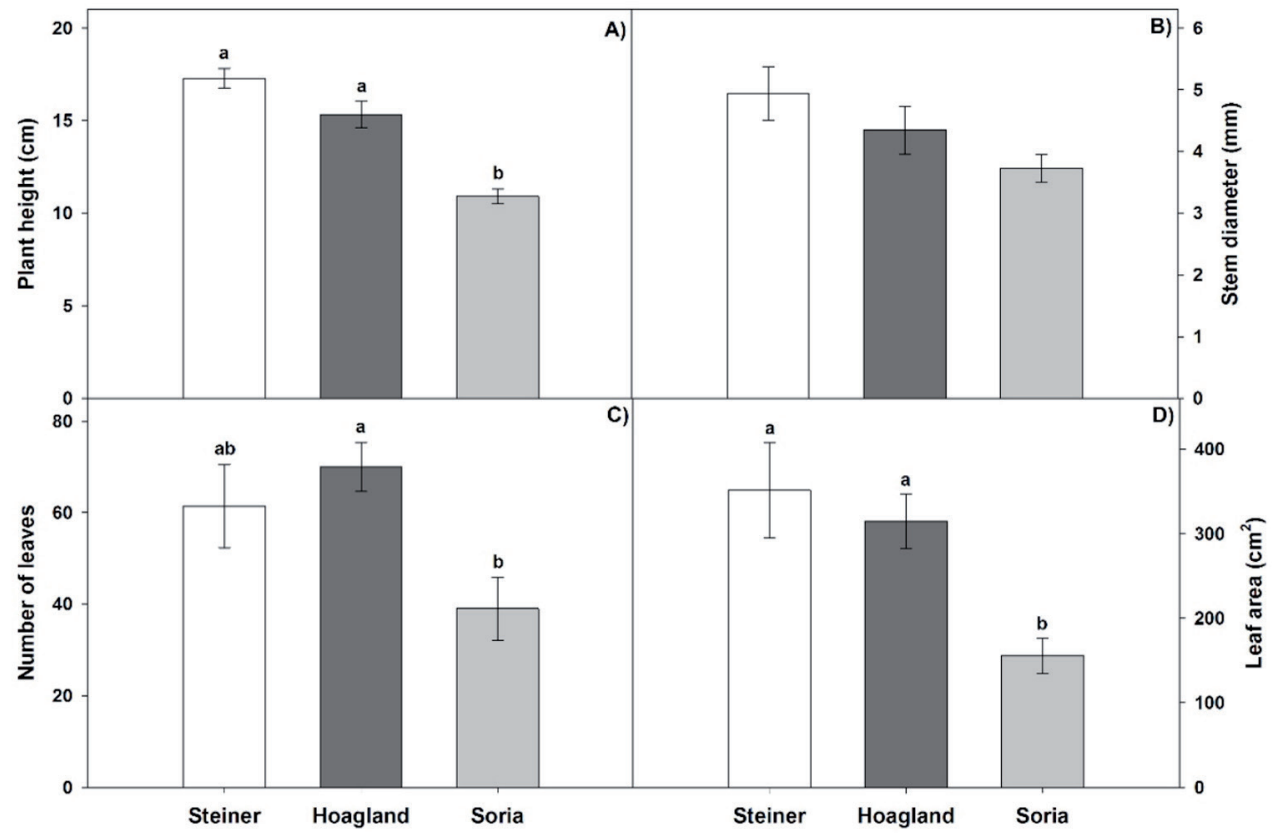

Data are means \pm SE; different letters show significant differences according to Tukey's test $(\alpha=0.05) ; \mathrm{n}=5$.

Figure 8. Leaf (A), stem (B), root (C) and total (D) dry mass in habanero pepper plants with three nutrient solutions.

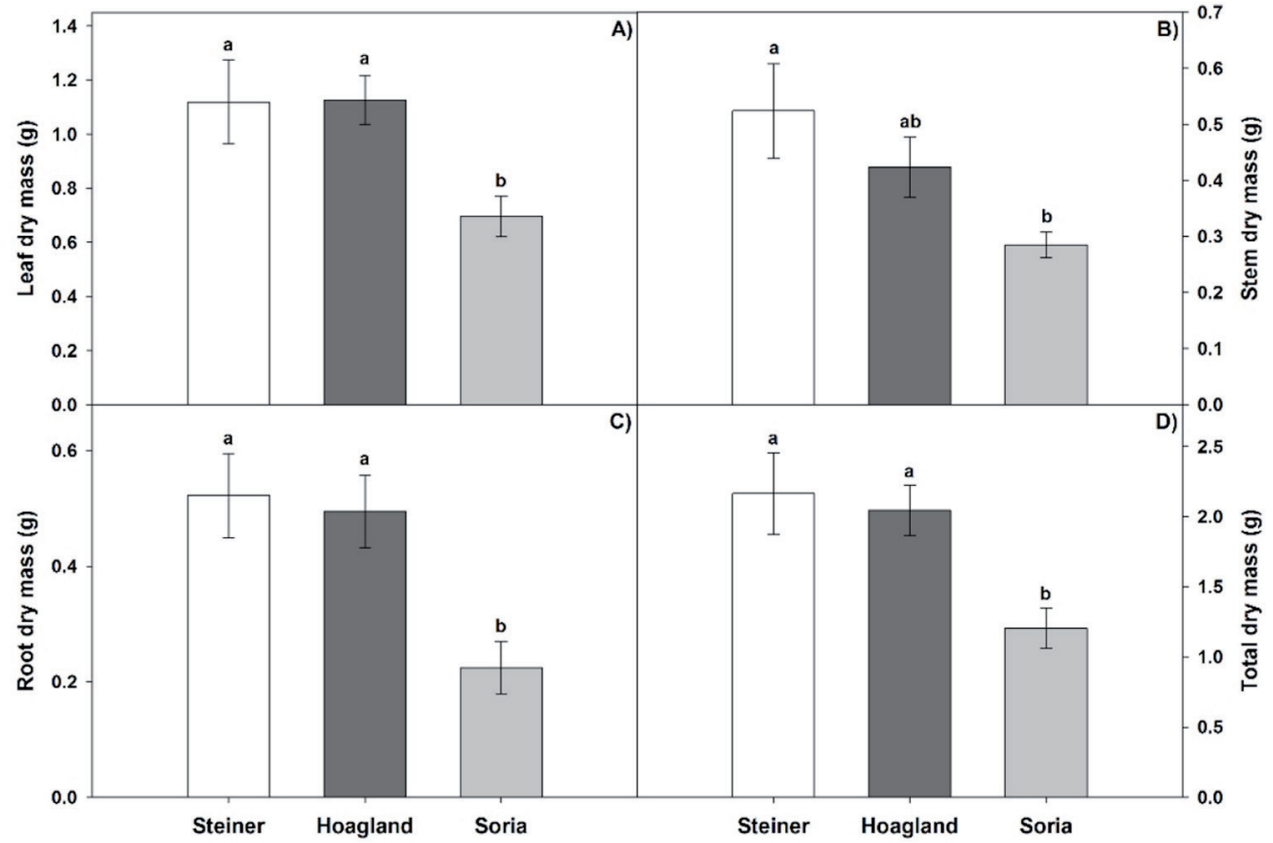

Data are means \pm SE; different letters show significant differences according to Tukey's test $(\alpha=0.05) ; \mathrm{n}=5$. 


\section{CONCLUSIONS}

Steiner and Hoagland solutions provide greater $\mathrm{K}, \mathrm{Ca}, \mathrm{Mg}, \mathrm{Cu}$ and $\mathrm{Zn}$ concentrations to habanero pepper plants. Macronutrient accumulation formed a gradient from least to greatest from roots to leaves, whereas micronutrient accumulation was the opposite. Also, these treatments increase chlorophyll synthesis ( $a, b$ and total), electron transport rate, light-saturated $\mathrm{CO}_{2}$ assimilation rate, maximum photosynthetic rate, maximum catalytic activities of Rubisco and maximum rate of electron transport demand for RuBP regeneration, saturation points in photosynthetic $\mathrm{CO}_{2}$ response curves and photosynthetic light response curves, and growth parameters (plant height, number of leaves, leaf area, dry mass). Plants with Hoagland solution uptake nitrate and store it in the cells of leaves and roots. Nitrogen assimilation in plants with Steiner solution is used for amino acids, whereas in the control solution it is used for proteins.

\section{ACKNOWLEDGEMENTS}

Thanks to Consejo Nacional de Ciencia y Tecnología (CONACYT) for the scholarship granted to Rocío E. Meneses Lazo for postgraduate studies.

\section{REFERENCES}

Aftab, T., and Hakeem, K.R. 2020. Plant micronutrients: deficiency and toxicity management. Springer International Publishing. Cham, Switzerland. doi:10.1007/978-3-030-49856-6.

Albanese, P., Manfredi, M., Meneghesso, A., Marengo, E., Saracco, G., Barber, J., et al. 2016. Dynamic reorganization of photosystem II supercomplexes in response to variations in light intensities. Biochimica et Biophysica Acta 1857:1651-1660. doi:10.1016/j.bbabio.2016.06.011.

Alejo-Santiago, G., Luna-Esquivel, G., Sánchez-Hernández, R., Salcedo-Pérez, E., García-Paredes, J.D., and Jiménez-Meza, V.M. 2015. Determination of nitrogen requirement for habanero pepper (Capsicum chinense Jacq.) Revista Chapingo Serie Horticultura 21(3):215-227.

Asao, T. 2012. Hydroponics - A standard methodology for plant biological researches. InTech, Rijeka, Croatia. doi:10.5772/2215. Barker, A.V., and Pilbeam, D.J. 2015. Handbook of plant nutrition. $2^{\text {nd }}$ ed. CRC Press, Taylor and Francis Group, New York, USA.

Bradford, M.M. 1976. A rapid and sensitive method for the quantitation of microgram quantities of protein utilizing the principle of protein-dye binding. Analytical Biochemistry 72(1-2):248-254.

Cawse, P.A. 1967. The determination of nitrate in soil solutions by ultraviolet spectrophotometry. Analyst 92(1094):311-315.

Chen, M., Schliep, M., Willows, R.D., Cai, Z., Neilan, B.A., and Scheer, H. 2010. A red-shifted chlorophyll. Science 329:13181319. doi:10.1126/science.1191127.

Ethier, G.J., and Livingston, N.J. 2004. On the need to incorporate sensitivity to $\mathrm{CO}_{2}$ transfer conductance into the Farquhar-von Caemmerer-Berry leaf photosynthesis model. Plant, Cell and Environment 27:137-153.

Fu, W., Li, P., and Wu, Y. 2014. Effects of different light intensities on chlorophyll fluorescence characteristics and yield in lettuce. Scientia Horticulturae 135(24):45-51.

Garruña-Hernández,R.,Latournerie-Moreno,L.,Ayala-Garay,O.,Santamaría,J.M.,y Pinzón-López,L.2014.Acondicionamiento pre-siembra: Una opción para incrementar la germinación de semillas de chile habanero (Capsicum chinense Jacq.) Agrociencia 48:413-423.

Gayosso-Rodríguez, S., Villanueva-Couoh, E., Estrada-Botello, M.A., y Garruña, R. 2018. Caracterización físico-química de mezclas de residuos orgánicos utilizados como sustratos agrícolas. BioAgro 30(3):177-188.

Hoagland, D.R., and Arnon, D.I. 1950. The water-culture method for growing plants without soil. California Agricultural Experiment Station. Circular 347. College of Agriculture, University of California, Berkeley, California, USA.

Marschner, P. 2012. Marschner's mineral nutrition of higher plants. $3^{\text {th }}$ ed. Elsevier, New York, USA.

Meneses-Lazo, R.E., y Garruña, R. 2020. El cultivo de chile habanero (Capsicum chinense Jacq.) como modelo de estudio en México. Tropical and Subtropical Agroecosystems 23(21):1-17.

Meneses-Lazo, R.E., Garruña-Hernández, R., Latournerie-Moreno, L., Andrade-Torres, J.L., y Pérez-Gutiérrez, A. 2018. Caracterización fenológica y fisiológica de variedades experimentales de chile habanero con alto potencial agronómico. Revista Fitotecnia Mexicana 41(1):67-74.

Na, L., Li, Z., Xiangxiang, M., Ara, N., Jinghua, Y., and Mingfang, Z. 2014. Effect of nitrate/ammonium ratios on growth, root morphology and nutrient elements uptake of watermelon (Citrullus lanatus) seedlings. Journal of Plant Nutrition 37(11):1859-1872. doi:10.1080/01904167.2014.911321. 
Nieves-González, F., Alejo-Santiago, G., Luna-Esquivel, G., Lemus-Flores, C., Juárez-López, P., y Salcedo-Pérez, E. 2015. Extracción y requerimiento de fósforo en chile habanero (Capsicum chinense Jacq.) 'Big Brother'. Interciencia 40(4):282-286.

Pacheco-Arjona, J.R., Ruiz-Lau, N., Medina-Lara, F., Minero-García, Y., Echevarría-Machado, I., De los SantosBriones, C., et al. 2011. Effects of ammonium nitrate, cesium chloride and tetraethylammonium on high-affinity potassium uptake in habanero pepper plantlets (Capsicum chinense Jacq.) African Journal of Biotechnology 10(62):13418-13429. doi:10.5897/AJB10.2097.

Samaniego-Gámez, B.Y., Garruña, R., Tun-Suárez, J.M., Kantun-Can, J., Reyes-Ramírez, A., and Cervantes-Díaz, L. 2016. Bacillus spp. inoculation improves photosystem II efficiency and enhances photosynthesis in pepper plants. Chilean Journal of Agricultural Research 76:409-416. doi:10.4067/S0718-58392016000400003.

Santiago-Antonio, G., Lizama-Gasca, M.G., Carrillo-Pech, M., and Echevarría-Machado, I. 2014. Natural variation in response to nitrate starvation among varieties of habanero pepper (Capsicum chinense Jacq.) Australian Journal of Crop Science 8(4):523-535.

Sekhar, K.M., Rachapudi, V.S., Mudalkar, S., and Reddy, A.R. 2014. Persistent stimulation of photosynthesis in short rotation coppice mulberry under elevated $\mathrm{CO}_{2}$ atmosphere. Journal of Photochemistry and Photobiology B: Biology 137:21-30. doi:10.1016/j.jphotobiol.2014.05.001

Soria, M., Trejo, J., Tun, J., y Terán, R. 2002. Paquete tecnológico para la producción de chile habanero (Capsicum chinense Jacq.) Secretaría de Educación Pública, Subsecretaría de Educación e Investigación Tecnológicas (SEP-SEIT-ITA). Instituto Tecnológico Agropecuario N 2, Conkal, Yucatán, México.

Staley, C., Breuillin-Sessoms, F., Wang, P., Kaiser, T., Venterea, R.T., and Sadowsky, M.J. 2018. Urea amendment decreases microbial diversity and selects for specific nitrifying strains in eight contrasting agricultural soils. Frontiers in Microbiology 9:634. doi:10.3389/fmicb.2018.00634.

Steiner, A.A. 1984. The universal nutrient solution. p. 633-650. In Proceedings of the $6^{\text {th }}$ International Congress on Soilless Culture, Lunteren. 29 April-5 May. Secretariat of International Society for Soilless Culture (ISOSC), Wageningen, The Netherlands.

Tucuch-Haas, C.J., Alcántar-González, G., Ordaz-Chaparro, V.M., Santizo-Rincón, J.A., y Larqué-Saavedra, A. 2012. Producción y calidad de chile habanero con diferentes relaciones $\mathrm{NH}_{4}{ }^{+} / \mathrm{NO}_{3}{ }^{-}$y tamaño de partícula de sustratos. Terra Latinoamericana 30:9-15.

Val, J., Heras, L., and Monge, E. 1985. New formulae for the determination of photosynthetic pigments in acetone. Anales de la Estación Experimental Aula Dei 17(3-4):231-238.

von Caemmerer, S., and Farquhar, G.D. 1981. Some relationships between the biochemistry of photosynthesis and the gas exchange of leaves. Planta 153:376-387. doi:10.1007/BF00384257.

Yemm, E.W., and Cocking, E.C. 1955. The determination of amino-acids with ninhydrin. Analyst 80(948):209-214. doi:10.1039/an9558000209.

Zhang, K., Wu, Y., and Hang, H. 2019. Differential contributions of $\mathrm{NO}_{3}{ }^{-} / \mathrm{NH}_{4}{ }^{+}$to nitrogen use in response to a variable inorganic nitrogen supply in plantlets of two Brassicaceae species in vitro. Plant Methods 15:86. doi:10.1186/s13007-019-0473-1. 